\title{
SHOULD A PREACHER PARTICIPATE IN THE POLITICAL LTFE OF HIS COUNTRY? IF SO, WHY AND HOW?
}

\author{
By Arthur Yager, Ph. D., Georgetown, Ky.
}

Our preachers have in the past, neglected this patriotic duty. They have been poor citizens, in this respect, and have not rendered unto Cæsar the things that are Cæsar's.

It seems to me that there have been two fundamental reasons for this neglect. (1) There is a religious reason: There still lingers in some quarters an old idea of our religion, which makes it appear somewhat inconsistent for a preacher to meddle much with any of the practical affairs of this life-a notion that the chief concern of the preacher was to warn men to flee from the wrath to come, to make their peace with God, to keep that peace largely by disentangling themselves with the affairs of this present world. The preacher's mission was to conserve the spiritual life, and the spiritual life was in direct opposition to the temporal life. Now of all forms of temporal life politics is undoubtedly the worst, the most earthy. That celebrated trio, the world, the flesh, and the devil, have heretofore had more complete charge of our politics than any other earthly concern of equal importance. So the conclusion was obviousthe preacher must absolutely leave it alone.

As an illustration of this old idea of religion in extreme form I will quote the authoritative official definition of our religion found in the circular letter of Elkhorn Association, printed in 1805. "By the religion of Jesus we mean the implantation of the Divine graces of the Holy Spirit, which leads all of the children of God to discover the entire insufficiency of all created enjoyments and human and creature righteousness to make them happy, or accepted with God; discovers to them the suitable- 
ness and entire sufficiency of the dear Redeemer, and enables them to believe and rejoice in him as their all in all."

There is here no mention of missions or service or work of any sort, for the bringing in of the Kingdom of God, or the uplifting and purification of this world.

Everybody I think would now admit that this is a onesided definition of "the religion of Jesus." At any rate our modern religion is far more militant and practical than this. It attacks sin and evil everywhere, not only in the heart of the believer, but also in government, in society, in business and in pleasure. Therefore a preacher of this great religion of Jesus, can not be indifferent to the wrong in politics, or anywhere else.

But there is also a political reason for the attitude of many preachers toward polities, and that is the old democratic, Jeffersonian view of politics, as a matter of small importance in the total life of the country.

Government, according to this view, is regarded as a necessary evil; its operations, therefore, are to be restricted to the narrowest possible limits. As an agent in the common life, it is never to be called on except for the performance of those activities which could not be performed by the people themselves.

In our Federal constitution and State constitutions, drawn up and adopted during the first century of our national life, we have attempted to hedge our governm'ents about with innumerable restrictions; attempting in this way to limit their powers, and cut down their activities as much as we possibly could, and leave the largest part of our affairs free from any intermeddling on the part of the Nation.

It is easy to account historically for this political theory. It was a part of the radical individualistic philosophy which became regnant after the French Revolution. The rights of man became almost a fetish to be worshipped, and it was made to mean almost entire freedom from every kind of restraint. All government everywhere was looked upon with suspicion by our political 
forebears. It was regarded as an agency always liable to become inefficient, corrupt and oppressive, dangerous to liberty and to the free life of the individual and of the Church. And our people, therefore, strove to cut it out as much as possible from the untrammeled life of the community. "That government is best which governs least," said Thomas Jefferson; and for a half century after he said it, we struggled to realize that ideal.

We have only recently seen clearly how futile has been that struggle. Government--that is, the political lifehas grown in power, in importance, and in the multiplicity of affairs with which it deals, steadily and irresistibly, until now it puts its potent hand upon almost every vital matter connected with our lives. It is easy to show the onward march of governmental work and activity. Take for example, the matter of charity. The Church used to be the great almoner; now it is the City, the County, the State, that does the largest part of this work.

Take for example, the matter of Education. Public education, that is, education supported by the Government, has grown to such proportions that it is now a question as to whether it will not soon lay its doomful hand upon every kind of school in the country, save, perhaps, the Theological Seminary. But perhaps the growth of government activities can be most strikingly illustrated by comparison of the government revenues and expenditures of the present day, with those of 80 or 100 years ago.

The income of the F'ederal Government before the Civil War never rose above $\$ 50,000,000$ annually; while now, for this present year, they will far exceed one billion dollars. Our population is not more than three times as great as then; our expenditures are twenty or thirty times as great.

The budget of every City and State shows the same stupendous tendency to increase. It is futile to try to stop this irresistible tendency, even if we wished to do so, and it is doubtful if we should wish to do it. Govern- 
ment is the agency that belongs to all of us, and our obvious duty is to make it represent all of us, and the lesson I will draw from this sketch of the political evolution of our country, is for all of us to try to get into the political game, and make the enormous and increasing influence of government responsive to the best and highest aspirations of the whole community.

But these reasons which in my judgement have tended in the past to keep the Preacher entirely aloof from the politics of the community, have passed away never to return; and there are now many and strong reasons why he should interest himself in that life, and strive to promote its purification and proper development.

In the first place, a preacher is not simply and solely a preacher. He is also a man-a full-rounded, redblooded man, and a citizen, and he has no warrant for merging in his professional character as a minister, all of his rights and responsibilities and duties as a citizen. "Render unto Cæsar, the things that be Cæsar's" - not neglecting, of course, the things that belong to God.

We Baptists especially have always contended against sacerdotalism. It is not necessary that a preacher should cease to be a man, and become nothing but a preacher-that he should dress his profession, and look his profession, act his profession, and merge even his individuality in his calling.

A minister, in addition to his character as minister, is also usually the head of a family-the owner of property-a member of the body politic; and by virtue of all these social relations, he has political duties which he ought not to shirk.

The early constitution of Kentucky contained a provision that no preacher should ever hold any political office in the Commonwealth. John L. Waller, one of our greatest preachers, who was a member of the third constitutional convention, combatted that provision in one of the strongest and most eloquent arguments ever made in the legislative halls of Kentucky. 
Because of his efforts and influence, this provision was wisely cut out of our later constitutions.

The Preacher is coming more and more to be recognized as a great social leader in the community where he lives, and every form of social and moral uplift should appeal to his interests, and command his coöperation And I shall presently show, nothing is so important to the moral and social life in this 20 th century as the puri. fication of politics.

In the second place, the Minister should lend a hand in the political struggles going on about him, because of their great, and ever increasing importance. As stated before, the province of our government can no longer be restricted to a comparatively few concerns. This province is widening year by year, and the government, federal, state, and city, is constantly increasing its activities, and undertaking to render more and more services for the people; and there is no sign that this tendency is soon to be checked. In business, in education, in philanthropy, in the regulation and control of our economic and social life, its powerful hand is seen everywhere. The old individualistic philosophy has given way before the new ideas of the sphere of Government. With this idea in our minds, it would be interesting to sit down and read the platforms of the three great political parties of last year, and compare these with the political platforms of say, 1872, or even 1892. Or, take the recent platform of the Progressive party, and compare it with any other platform ever promulgated by any great political party, in our previous history. And while its ideals have been stigmatized as visionary, and its methods as impractical, let us remember that it rallied to its support about four million voters in its first campaign, not to count the other millions of progressives who voted for other tickets. Now, the fundamental political doctrine underlying all the progressivism of modern polities is, that the Government is a great instrumentality belonging to all the people, and ean properly be used by them for the secur- 
ing of social justice, for the correction of economic as well as political abuses, and for the moral uplift of society. This doctrine implies that society is an organism with a life and development of its own; and that the Government is its most important organ, through which it can work out its destiny, according to its own ideals. This sort of politicalism - if I may be permitted to coin a word-is simply a modification of modern socialism. By the last word I do not mean all of the technical shibboleths by which the Socialist is distinguished from other reformers; but I mean rather the socialistic spirit which emphasizes the social view-point and calls upon the individual to make personal sacrifices for the social good.

It may be that some of us do not approve of all this clamor for social and economic reform, which has entered into later day politics; but of one thing we may rest assured, our political life will never again be what it has been in the last century. It will be larger, and fuller, of deeper moral significance. In an important sense, society is an organism, unified, integrated, as an evolutionist would say, around its political organization. Every part of it is organically related to every other part, as is so graphically set forth in I Cor. 12, concerning the body of Christ. We can not separate one phase of its life from another; it is not built in water-tight compartments, like a ship, so that one part of it can be dry and clean, and another part flooded with corruption and vice.

This has been abundantly proved by our experience, for we have seen the graft, the greed and the selfishness of our politics overflow and contaminate our business life and our social life everywhere. And the remedy is not to attempt to build dikes against the flood of wrong in our politics, and try thus to localize it, but to carry the war into Africa, and to demand and work for the purification of our political methods. All this constitutes a challenge to the Preacher, to turn his batteries upon the citadel of sin. 
In the third place our politics need our preachers sorely. I do not mean by this simply that polities needs the moral purification that preachers might perhaps help to give it, but rather in a philosophical sense our political life sorely needs to have a new life poured into it.

There is need of a new element, the problems need to be attacked from a new direction. I am sure the public. mind sees this need. There has been too great a preponderance of the legal element in our public life. In no country in the world have lawyers, as such, had so much influence as in the United States. Ours has sometimes been characterized as a government of lawyers, for lawyers and by lawyers.

And now granting that a Preacher should participate more or less actively in the political life of his country, let us give a brief consideration to the third part of the subject: How can he do so?

This is a perplexing problem. How can a minister of the gospel do this thing without hampering and hindering him in his great work as a preacher and pastor? Each one must of course judge of the conditions of his own community, and after he has discerned the voice of consicence, try in some way tactfully to use his great influence for the right. No cast-iron rules can be laid down. It will oftentimes be a delicate and difficult matter, and perhaps sometimes impossible for a preacher to do what he may know to be right, in a heated political campaign, without perhaps causing more injury in other directions than the good that may be accomplished.

I am endeavoring to create a state of thoughtful consideration as to what a preacher, under normal conditions ought to do, if he can, rather than to lay down hard and fast rules of conduct for all situations. But some suggestions may be made that I am sure will be generally helpful. First: Our preachers should of course, like all other citizens, make a careful study of the complicated mechanism through which the government of our great 
country is actually carried on. For nothing can be done without a knowledge of the machinery and the methods by which political work is done.

When we consider the entire fabric of American government, federal, state and local, as it has developed through the years, it is by no means a simple combination of political machinery. Our fathers who started it in 1789 when they adopted the great Constitution of the United States were very much under the influence of the philosophy of the universe, produced by the discoveries of Sir Isaac Newton; and they framed a government which was to work somewhat after the analogy of the heavenly bodies, which are balanced in space and move about under the force of gravitation. It was a government of checks and balances consisting of great co-ordinate departments, moving around in orbits of their own, checking, and yet not interfering with one another.

Underneath the Federal Government, the State and City governments were formed on the same model, and all were put together in an inter-locking, and counterbalancing system. Later, and quite unexpectedly, the great system of political parties was built up and superimposed upon the original structure. Our fathers did not provide for this, because they did not anticipate it. In fact they had a deep and abiding distrust for a genuine democracy or rule of the people, as we understand it today. And it is a real rule of the people that makes political parties necessary. Our political parties grew up and worked for almost a century without any warrant for their existence, in the constitution, or in the laws of the land. As they grew in power and organization they developed an almost despotic power over their adherents, and developed at their centers, these political machines, with which we are so familiar at the present day.

Then came the economic evolution of those gigantic corporations, in the mysterious purlieus of which the Big Business hides its demands for special privileges and monopolies. And as the offspring of big business and po- 
litical machines, we get the party boss-that most sinister of all the figures in our latter day politics.

These modern products of our political system have played ducks and drakes with the stately machinery of our fathers. They have often paralyzed Executives, thwarted our Courts, dead-locked our Legislatures and Congresses and at every turn hampered and clogged the working of our political machinery.

All of this must be carefully studied and intelligently considered by any citizen who would be useful in the political life of his country. He must know where to begin -where first to take hold, in order to be of any use ; and usually the best place to begin is at the bottom-at the precinct primary of his party, where machines are made, and bosses are born. In the second place it is these same political parties with their intense partizanship and rigorous dicipline that constitute the chief embarrassment of a minister who would try to serve the cause of righteousness, in a political way. IIis members belong to both parties, and they usually resent their pastor's participation in the political debate, as an unwarranted intrusion on his part. Moreover, if he belongs to one party, and fails to obey the orders of the machine, he is scorned as a bolter, and his religious influence endangered. But here again our recent history gives us comfort.

I think that it could be shown that now in this year of grace 1913, a clear majority of the voters of our great Republic are bolters, for when we add to the great army of Democrats who have in various recent elections broken away from their party, the four million of Progressives who bolted the nominee of their party, in the last election, we shall have a majority, perhaps, of all the voters in the country.

In fact the great party system which has so long dominated the political life of our country, seems to be almost in ruins. And while it will doubtless be revived, it will be built up along other lines, and upon different principles. 
Should a Preacher Participate in the Political Life? 397

The day of party tyranny is over. Moreover, the rapid introduction of women voters into our systemwhich seems bound to go on until it has spread over our whole country-will bring a new element into our political life; and inasmuch as it could not make it worse, it must needs improve it. 